\title{
Multi-scale distribution and dynamics of bivalve larvae in a deep atoll lagoon (Ahe, French Polynesia)
}

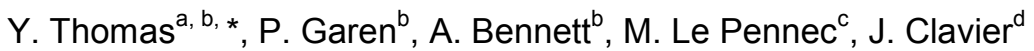

\author{
a Ifremer, DPFOM LPI, Presqu'île du Vivier, 29840 Argenton, France \\ ${ }^{\mathrm{b}}$ Ifremer, COP, BP 7004, 98719 Taravao, Tahiti, French Polynesia \\ c Université de Polynésie Française, BP 6570, 98702 Faa'a, Tahiti, French Polynesia \\ d CNRS, UMR 6539 (LEMAR), IUEM, Technopôle Brest-Iroise, Place N. Copernic, 29280 Plouzané, France \\ *: Corresponding author : Yoann Thomas, tel : +33 2988929 43; fax : +33 0298892959 ; \\ email address : yoann.thomas1@gmail.com
}

\begin{abstract}
:
Bivalve larvae and hydrographic parameters were sampled over a range of spatio-temporal scales in a deep atoll lagoon. Bivalve larvae abundances were very high throughout the year: $18,550 \mathrm{~m}^{-3}$ in average. Larvae were (i) concentrated at mid-depth with nocturnal ascent and diurnal descent, (ii) heterogeneously dispersed at the lagoon scale, (iii) subject to day-to-day variation in abundance and (iv) transferred between different parts of the lagoon providing evidence of intra-lagoonal connectivity. The primacy of physical factors was seen on large spatial scale with the diluting effect of water renewal and transfers by hydrodynamics. On smaller spatial scale, the primacy of biological processes was recognised, with larval swimming activity leading to dial vertical migration correlated with food concentration. Variations in larval abundance were driven by bivalve reproductive activity correlated with meteorological conditions (i.e. windy periods). Finally, relationship between bivalve larvae patterns and pearl oyster (Pinctada margaritifera) settlement structuring is discussed.
\end{abstract}

\section{Highlights}

Bivalve larvae distribution patterns were studied in a deep atoll lagoon. Bivalve larvae abundances were very high throughout the year. The primacy of physical factors was seen on large spatial scale. Biological processes (swimming, spawning) were recognised to drive small-scale patterns. We demonstrated the relationship between larvae abundance and Pinctada margaritifera settlement.

Keywords: Bivalve larvae ; Distribution patterns ; Vertical migration ; Pinctada margaritifera settlement ; Deep atoll lagoon ; French Polynesia

\section{Introduction}

The majority of marine invertebrates have a planktonic larval stage at the beginning of their lives. This planktonic step appears to be a key determinant for adult distribution and abundance since the distribution and abundance of sessile populations are determined by a combination of pre- and postsettlement factors (Olson and Olson 1989; Cowen et al., 2000; Levin 2006). Besides endogenous factors, like feeding capacity and metabolic processes 
(Pace et al., 2006), bivalve larval growth and survival depend on external pressures from predation (Troost et al., 2009) and a wide variety of environmental factors, i.e. temperature, salinity, food quality and availability (Eckman 1996; Doroudi et al., 1999; Powell et al., 2002; Hofmann et al., 2004). Moreover, as for all zooplankton communities, bivalve larvae distributions exhibit spatial patterns (Pinel-Alloul 1995; Avois-Jacquet 2002). These patterns are generated and maintained by physical factors, like hydrodynamics, and biological processes such as larval swimming activity (Haury et al., 1978; Garland et al., 2002; Masson et al., 2004; Badylak and Phlips 2008). Since zooplankton distributions and environmental processes are 'scale-dependent', a range of spatial and temporal scales should be considered for studying zooplankton variability and understanding its driving mechanisms (Borcard et al., 2004).

The determinants of marine population dispersal remains one of the fundamental challenges for marine ecology and oceanography (Cowen et al., 2006). In tropical ecosystems, numerous studies address fish or coral larval dispersal, mainly to understand the connectivity between source and recipient sectors so as to protect, preserve and manage biodiversity (Roberts 1997; Swearer et al., 1999; Botsford et al., 2009; Munday et al., 2009). In atoll lagoons, the diversity and structure of mollusc populations are highly related to local factors like substrate types or hydrodynamic conditions (Pante et al., 2006). Nonetheless, most of the mechanisms explaining abundance and distribution variability of adult populations remain obscure and could be attributed to larval development success and settlement processes (Adjeroud et al., 2000).

In French Polynesian atoll lagoons, reared stocks of the black-lip pearl oyster (Pinctada margaritifera, Linné, 1756) are added to wild populations, increasing the abundances of bivalves. Pearl oyster farming plays a major socio-economic role in French Polynesia with 81 million euros in exports and about 5000 jobs in 2008 (ISPF, 2008). This activity is entirely sustained by the wild collection of juveniles on artificial collectors, although the levels of spat collected are unpredictable. Efficient management of $P$. margaritifera production requires the ability to understand distribution of larvae, and identify suitable zones for spat collection. Among the 15 French Polynesia collecting atolls, Ahe atoll is one of the main producers of $P$. margaritifera juveniles and was chosen as a reference site to study bivalve larvae ecology.

The goals of this study were to quantify the spatio-temporal heterogeneity of bivalve larvae abundances, and develop plausible scenarios involving physical or biological mechanisms to explain observed patterns of variation. The link between larval patterns and $P$. margaritifera settlement variability is discussed. 


\section{Material and methods}

\subsection{Sampling site}

Ahe atoll is located in the northwestern part of the French Polynesian Tuamotu Archipelago, $500 \mathrm{~km}$ northeast of Tahiti Island (Fig. 1). Ahe lagoon has a $145 \mathrm{~km}^{2}$ area with a mean depth close to $40 \mathrm{~m}$. Ahe is defined as a semi-enclosed atoll with a mean residence time of 34 days (Pagès and Andrefouet 2001; Dumas et al., this issue). One active pass is located in the western part of the lagoon and several reef-flat spillways (less than $50 \mathrm{~cm}$ depth) are distributed along the reef rim, mainly in the south and west part of the lagoon (Andréfouët and Yamano this issue). Almost $10 \%$ of the Ahe lagoon area is dedicated to black-lip pearl oyster rearing. The total stock of cultivated pearl oysters, located in breeding line and excluding spat on collectors, is judged to be 15 million individuals (Perliculture Service, pers. comm.), although the extent of the wild population remains unknown. With nearly 1240 spat collection stations and with 600 collectors per station, Ahe is one of the most important producers of pearl oyster juveniles in French Polynesia.

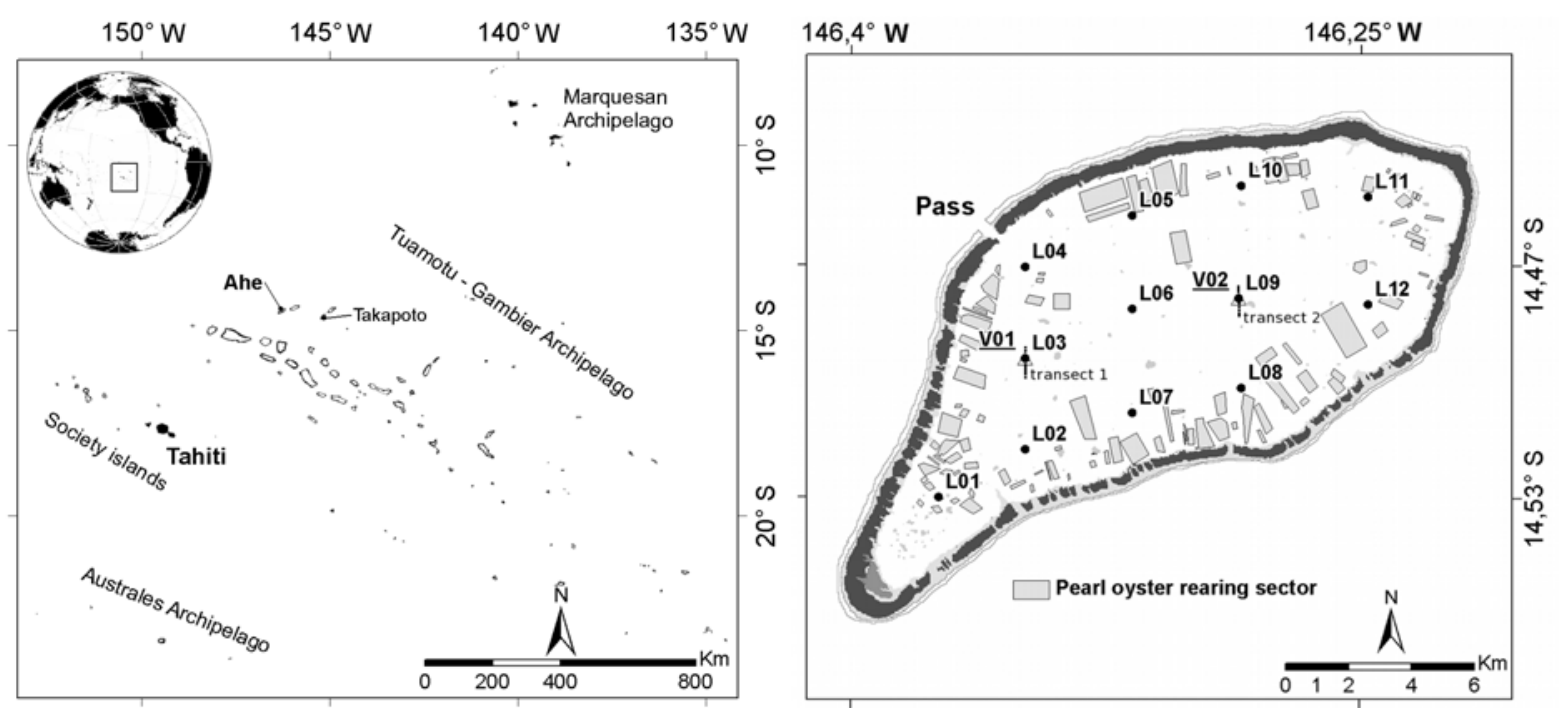

Fig. 1 Left: Localization of the Ahe lagoon. Right: Morphology of the Ahe lagoon and positions of the sampling stations in the lagoon; 'L': lagoon scale, 'V': vertical scale (24-h cycles), 'Transect': local scale 


\subsection{Sampling design}

A multi-scale spatial and temporal approach was developed to assess larval abundance and size distribution and hydrographic parameters at local (i.e. horizontal and vertical) and lagoon scales, according to nycthemeral, day-to-day and seasonal dynamics.

Day-to-day lagoon-scale sampling: Sampling was made at twelve stations (L01 to L12) distributed throughout the lagoon (Fig. 1). Stations were visited successively every two days in the morning, from L12 to L01. Water was sampled at each station from the surface to $5 \mathrm{~m}$ above the bottom. To assess the seasonal dynamics, four surveys were carried out, in AprilMay 2007, July-August 2007, November 2007 and February-March 2008. For technical reasons, day-to-day samplings were of different durations: 29, 15, 20 and 29 days during these periods, respectively.

Local transect: Two north south transects (Fig. 1) of ten stations separated by $100 \mathrm{~m}$ were sampled in the west and the central-east part of the lagoon, respectively. Water was sampled on each station from the surface to $5 \mathrm{~m}$ above the bottom. The two transects were successively sampled at 24-h interval. Three transect samplings surveys were carried out, in April 2007, May 2007 and July 2007, giving a total of 6 profiles; 3 for each transect.

24-h cycle vertical sampling: Two deep stations, V01 and V02 (50 m deep), located in the west and the central-east part of the lagoon, respectively (Fig. 1), were sampled over the whole range of five layers (0-10, 10-20, 20-30, 30-40 and 40-50 m). Each station was sampled with a frequency of $4 \mathrm{~h}$ from 08:00 h over a $24-\mathrm{h}$ cycle. The two stations were successively visited at a 24-h interval. These day/night cycles were studied in April 2007, July 2007 and February 2008, giving a total of six cycles; 3 for each station.

\subsection{Zooplankton sampling method}

Plankton was sampled from a boat by pumping at an average flow rate of $5 \mathrm{~m}^{3} \mathrm{~h}^{-1}$. A pipe of $32 \mathrm{~mm}$ diameter was connected to the pump and immersed to the sampling depth. The mean sample volumes were of 560, 740 and 430 litres for each of the lagoonal, transect and vertical samples, respectively. Pumped water was prefiltered on a $250 \mu \mathrm{m}$ mesh and plankton was retained on a $40 \mu \mathrm{m}$ mesh. Samples were immediately preserved in $72 \%$ ethanol. 
In the laboratory, each sample was transferred into a $16 \mathrm{~cm}$ diameter glass dish and spread evenly. Three transversal bands covering the dish width and disposed at the first quarter, middle and third quarter of the dish diameter were scanned at 6400 ppp with an Epson V750Pro scanner. The sum of the three scanned surfaces corresponded to $6 \%$ of the total dish surface and therefore to $6 \%$ of the total sample. On each scan, bivalve larvae were visually enumerated and automatically measured using NIvision ${ }^{\circledR}$ image analysing software. The major axis of the adjusted ellipse was used to describe larval size. In 2007, the specific identification of bivalve larvae was difficult and did not allow P. margaritifera and Pinctada maculata (Gould, 1850) to be distinguished (Paugam et al., 2006), thus no species distinction could be made at the larval stage for this study.

\subsection{Experimental spat collection}

We studied black-lip pearl oyster settlement concurrently with planktonic bivalve larvae distribution, in order to assess any direct links between them. Three experimental collectors, of the type used in the industry (i.e. loops of black flat polypropylene, knitted onto a $30 \mathrm{~cm}$ monofilament polyethylene line), were immersed at 6 depths $(5,10,15,25,35$ and $45 \mathrm{~m})$ at 2 stations (V01 and V02) for 6 weeks in April-May 2007, July-August 2007, NovemberDecember 2007 and February-March 2008. In the laboratory, spat were retrieved from the collectors and fixed in a $72 \%$ ethanol solution. Three groups: P. margaritifera, P. maculata and 'other bivalves' spat were identified and enumerated.

\subsection{Environmental parameters}

Vertical profiles of salinity (practical salinity unit), temperature $\left({ }^{\circ} \mathrm{C}\right)$ and in vivo chlorophyll $a\left(\mu \mathrm{g} \mathrm{l}^{-1}\right)$, were carried out in situ with a multi-parameter probe (SBE S19Plus, Sea-Bird Electronics, Inc.) at each sampling station. Hourly wind direction and velocity were obtained from Takaroa atoll meteorological station (Météo France data) located about $120 \mathrm{~km}$

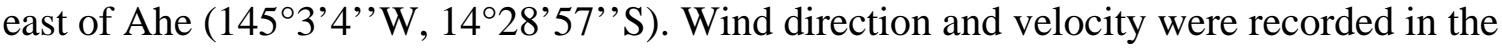
field with a mobile anemometer during the 24-h cycles. A detailed description of spatial and temporal variation of environmental parameters can be found in Thomas et al., (2010).

\subsection{Data analysis}

Median size was used to characterize the population of larvae species. Knowing the median size provides a first description of community composition by inferring the 
developmental stage and species structure. The coefficient of variation $(C V=\sigma / \mu)$ was calculated for larval abundance and size so as to quantify the degree of variability on various scales. To represent lagoon scales patterns, data were standardized by the standard score: $z=(V-\propto) / \sigma$ where $V$ is the median size value or larval concentration. After $\log (\mathrm{x}+1)$ transformation of abundances for data normalization and variance homogenisation, one-way ANOVA was applied to test the effects of space and time at the different scales. A post hoc Scheffé's pair-wise multiple comparison test was performed when significant differences were detected.

A Hierarchical Cluster Analysis (HCA), using similarity coefficient (i.e. Pearson correlation coefficient), was performed on all the daily abundances and median sizes ( $\mathrm{n}=$ 1200), to identify homogeneous groups of stations at the lagoon scale in order to ease result interpretations.

Spearman correlations were used to test the relationships between bivalve larvae abundances and environmental parameters. Since all the data of the 4 sampling campaigns were introduced to calculate the correlation coefficient, the distribution of the data did not reach the normality. This has motivated the choose of the Spearman's rank correlation coefficient, which makes the coefficient less sensitive to non-normality in distributions. Finally, the mean depth distribution of the larvae (ZCM), described by Fortier and Leggett (Fortier and Leggett 1982), was calculated for the 24-h cycles:

$$
Z C M=\sum c_{i} d_{i}
$$

where $c_{i}$, is the concentration frequency at the $i$ th depth interval and $d_{i}$, is equal to the mid-depth of the $i$ th interval.

\section{Results and discussion}

\subsection{Vertical structure and dynamics}

Bivalve larvae abundances were heterogeneously distributed through the water column ( $p$ $<0.001$ ) (Table 1, Fig. 2a). Larvae were concentrated between 15 and $35 \mathrm{~m}$ depth. The mean $\mathrm{CV}$ calculated on the whole vertical profile was $38 \%$. In addition, the population median size was unevenly distributed, with the largest larvae between 15 and 35 m depth (Fig. 2b). 

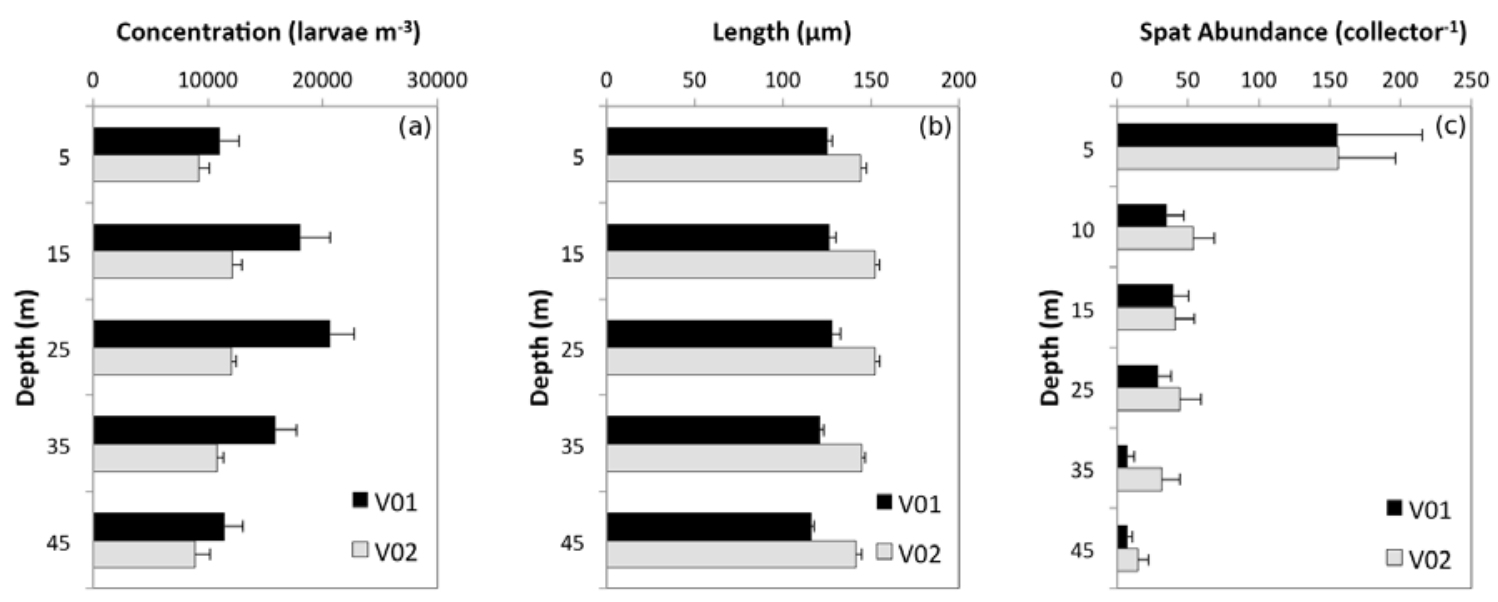

Fig. 2 Vertical patterns of (a) bivalve larvae abundance, (b) bivalve larvae median size and (c) P. margaritifera spat settlement density at the two stations V01 and V02. Data correspond to averages \pm standard error, calculated on the three sampling periods: April-May 2007, JulyAugust 2007 and February-March 2008.

Table 1. Results of the one-way ANOVA tests. In the comments column, numbers give the depth level (m) or the survey number (1: April-May, 2: July-August, 3: November and 4: February-March), and the letters give the homogenous groups.

\begin{tabular}{|c|c|c|c|c|c|}
\hline Parameter & Factor & DF & $\mathrm{F}$ & $\mathrm{p}$ & Comment \\
\hline \multirow{3}{*}{ Larval concentration } & Station & 1 & 18.03 & $<0.0001$ & V01 > V02 \\
\hline & Depth & 4 & 5.55 & 0.0003 & $5 a 15 b c 25 c 35 a b c 45 a b$ \\
\hline & Hour & 5 & 0.42 & 0.836 & $=$ \\
\hline \multirow{3}{*}{ Larval median size } & Station & 1 & 150.52 & $<0.0001$ & $\mathrm{~V} 01<\mathrm{V} 02$ \\
\hline & Depth & 4 & 4.76 & 0.001 & $5 a b \quad 15 a \quad 25 a \quad 35 a b \quad 45 b$ \\
\hline & Hour & 5 & 0.60 & 0.732 & $=$ \\
\hline \multirow{3}{*}{$\begin{array}{l}\text { P. margaritifera spat } \\
\text { density }\end{array}$} & Station & 1 & 8.53 & 0.006 & $\mathrm{~V} 01<\mathrm{V} 02$ \\
\hline & Survey & 3 & 5.18 & 0.004 & $1 \mathrm{a} 2 \mathrm{~b} \quad 3 \mathrm{~b} \quad 4 \mathrm{ab}$ \\
\hline & Depth & 5 & 9.57 & $<0.0001$ & $5 a \quad 10 a b \quad 15 a b c \quad 25 b c \quad 35 c \quad 45 c$ \\
\hline \multirow{3}{*}{$\begin{array}{l}\text { P. maculata spat } \\
\text { density }\end{array}$} & Station & 1 & 1.97 & 0.169 & $\mathrm{~V} 01=\mathrm{V} 02$ \\
\hline & Survey & 3 & 6.40 & 0.001 & $1 \mathrm{a} 2 \mathrm{~b} 3 \mathrm{ab} 4 \mathrm{a}$ \\
\hline & Depth & 5 & 7.91 & $<0.0001$ & $5 a b \quad 10 a \quad 15 a \quad 25 a b \quad 35 c 45 b c$ \\
\hline \multirow{3}{*}{$\begin{array}{l}\text { Other bivalves spat } \\
\text { density }\end{array}$} & Station & 1 & 10.317 & 0.003 & V01 < V02 \\
\hline & Survey & 3 & 11.15 & $<0.0001$ & $1 \mathrm{a} 2 \mathrm{c} 3 \mathrm{ab} 4 \mathrm{bc}$ \\
\hline & Depth & 5 & 8.63 & $<0.0001$ & 5a $10 \mathrm{a} \quad 15 \mathrm{a} \quad 25 \mathrm{a} 35 \mathrm{a} \quad 45 \mathrm{~b}$ \\
\hline
\end{tabular}


Larvae exhibited vertical migration according to the day/night cycles (Fig. 3, 4). No significant effect of the hour of the day was measured on the total concentration (Table 1), demonstrating the homogeneity of total abundances during the surveys. Larval abundances increased in the deeper layer during the day until 16:00 $\mathrm{h}$ and then increased in the upper layers until midnight. This cycle was mainly observed in the upper $10 \mathrm{~m}$ layer where larval concentration was systematically higher at night than during the day (Fig. 3). A slight variation of the mean depth distribution, ZCM, was measured with $26.5 \mathrm{~m}$ during the day and 23 at night (Fig. 4). This pattern implies nocturnal ascent and daytime descent but was disrupted by windy conditions, mainly during the two first surveys on the V02 station where day/night migration was not clear due to winds of 5.8 and $7.6 \mathrm{~m} \mathrm{~s}^{-1}$, respectively, comparing to the $3.8,3.8,3.7$ and $4.1 \mathrm{~m} \mathrm{~s}^{-1}$ measured during the 4 others surveys. No specific pattern could be identified in the median size (data not shown) according to 24-h dynamics.

The vertical heterogeneity of bivalve larvae abundance observed in Ahe atoll is in agreement with a previous study in the Takapoto lagoon, with maximum larval concentration at mid-depth (pers. comm. Garen). Similar patterns were described for bivalve larvae by Garland et al. (2002) in an inner-shelf of North Carolina (USA) and by Raby et al. (1994) in the Baie des Chaleurs, Quebec, Canada. Various stimuli were suggested that might explain the vertical swimming behaviour of bivalve larvae, like salinity or temperature discontinuity, light intensity, food availability or avoidance of predators (Raby et al., 1994; Knights et al., 2006). In Ahe lagoon, the vertical distribution was positively correlated with temperature and food concentration (i.e. Chl a in vivo) (Table 2). These results must be considered cautiously because correlations are not causal relationships. Nonetheless, temperature (or saline) discontinuities may have a significant influence on the vertical swimming ability (i.e. speed) of bivalve larvae (see e.g. Dekshenieks et al., 1996). But this influence was always described with high variation levels in $\mathrm{T}$ or $\mathrm{S}$ and mostly for species from temperate area. That is why; specific experimental protocols need to be developed to better know the effect of various $\mathrm{T}$ and $\mathrm{S}$ gradients on tropical species larvae. However, autotrophic communities and bivalve larvae seem to follow similar dial dynamics, apparently driven by light intensity, as suggested by the day/night pattern observed. This swimming behaviour is however hampered by windy conditions, probably due to water column homogenisation. No specific pattern was observed in median sizes of larval cohorts during the 24-h cycles studied. Species-specific larval behaviour at this stage could instead be invoked to describe the vertical distribution (Baker 2003). 

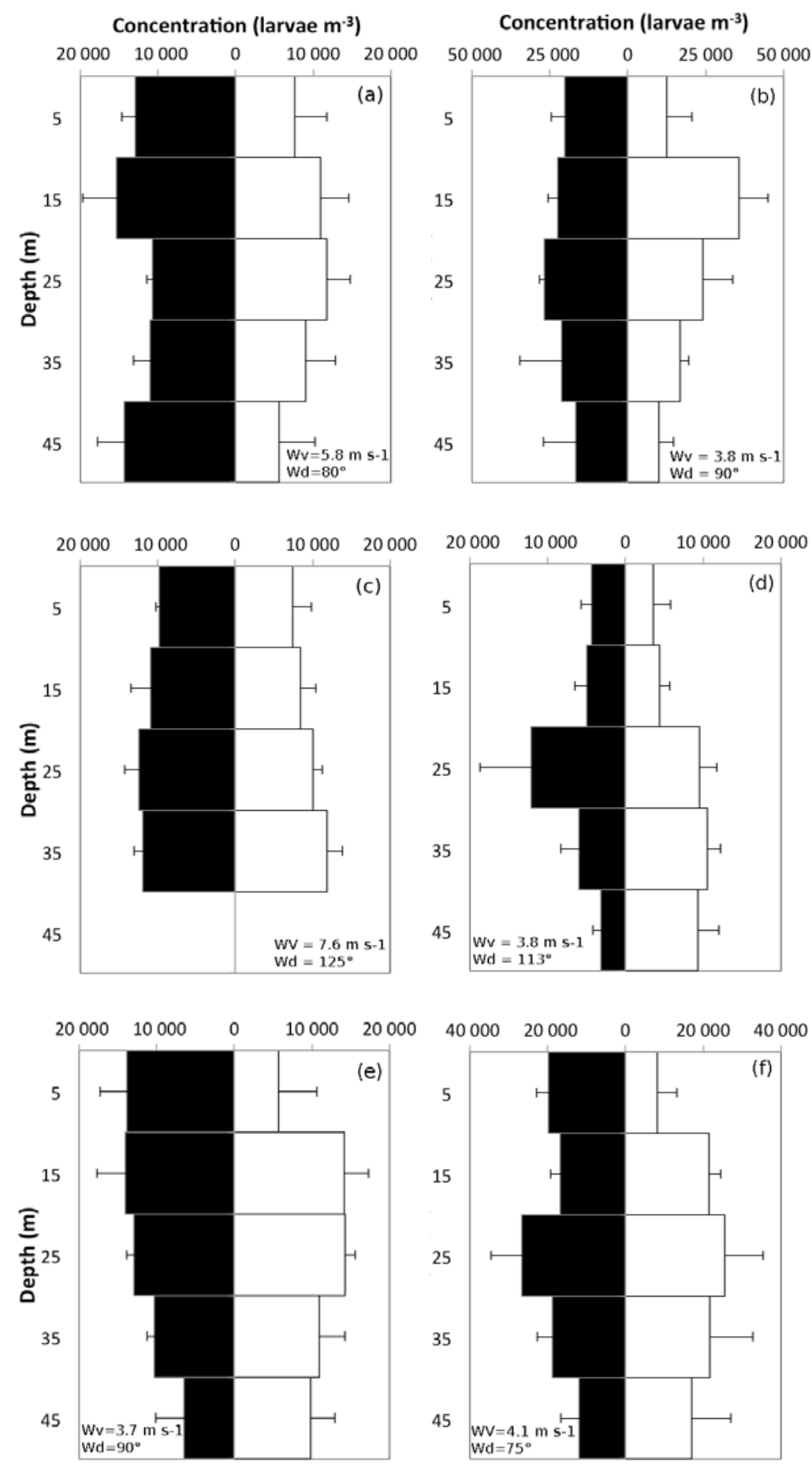

Fig. 3 Vertical distribution of bivalve larvae concentration ( \pm standard error) during the day (open) and at night (black): (a) V02-April 07, (b) V01-April 07, (c) V02-July 07, (d) V01-July 07, (e) V02-February 08 and (f) V01-February 08. Day means correspond to 4 measurements: 08:00, 12:00, 16:00 and 08:00 the second day and night means to 3 measurements: 20:00, 00:00 and 04:00. Wind velocity (Wv) and direction (Wd) are indicated on the plots. 


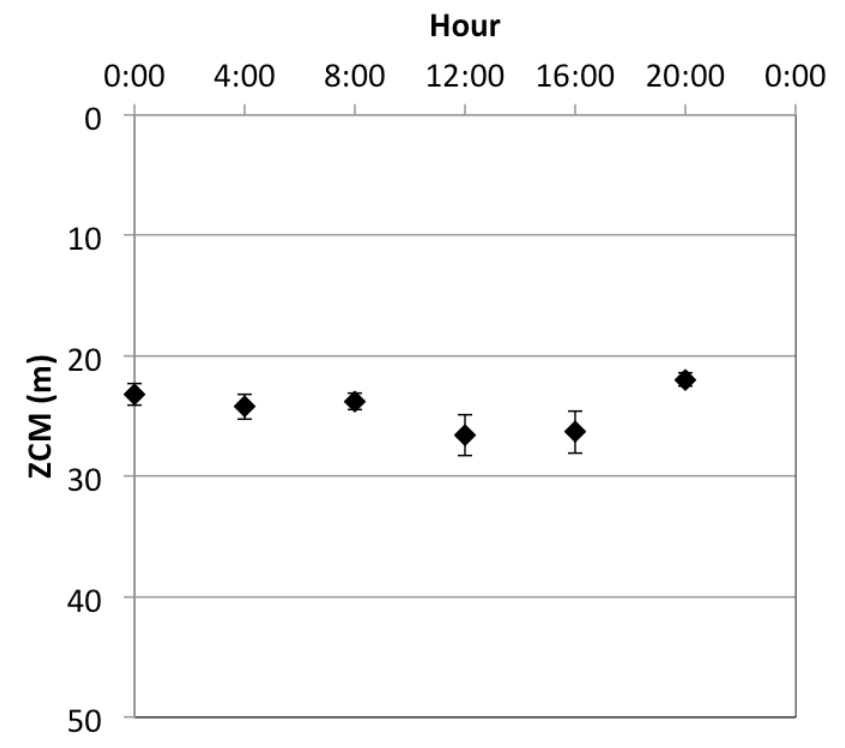

Fig. 4 Dial variation of the mean depth distribution of the larvae, ZCM. Data correspond to the averages \pm standard error calculated on the overall 24 -h cycles data set.

Table 2. Spearman correlation among the studied environmental parameters (LARV = larval abundance, $\mathrm{SAL}=$ Salinity, TEMP $=$ temperature, Chl $a=$ in vivo Chlorophyll-a, Dist pass $=$ distance from pass, Dist east-reef $=$ distance from eastern reef and $\mathrm{WV}=$ wind velocity) according to the three spatial scales studied $(* p<0.05, * * p<0.01$, *** $p<0.001)$

\begin{tabular}{|c|c|c|c|c|c|c|}
\hline \multicolumn{2}{|c|}{ Scale } & LARV & SAL & TEMP & Chl $a$ & $\begin{array}{l}\text { Dist } \\
\text { pass }\end{array}$ \\
\hline \multirow{6}{*}{ 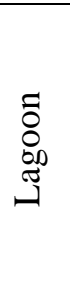 } & SAL & 0.04 & & & & \\
\hline & TEMP & 0.06 & -0.06 & & & \\
\hline & CHLA & 0.07 & $0.30 * * *$ & $0.37 * * *$ & & \\
\hline & Dist pass & $0.42 * * *$ & 0.03 & $-0.09 *$ & $0.08^{*}$ & \\
\hline & Dist east-reef & $-0.37 * * *$ & 0.02 & 0.01 & $-0.16^{* * *}$ & $-0.85 * * *$ \\
\hline & WV & 0.04 & $0.17 * * *$ & $0.13 * *$ & $0.12 * *$ & - \\
\hline \multirow{5}{*}{ 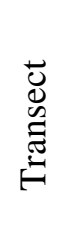 } & SAL & $-0.39 * *$ & & & & \\
\hline & TEMP & 0.02 & $-0.59 * * *$ & & & \\
\hline & CHLA & $0.30 *$ & -0.16 & 0.14 & & \\
\hline & Dist pass & 0.07 & 0.05 & $-0.26^{*}$ & $0.34 * *$ & \\
\hline & Dist east-reef & -0.19 & -0.06 & 0.24 & $-0.29^{*}$ & $-0.75^{* * *}$ \\
\hline \multirow{3}{*}{ 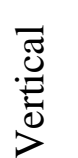 } & SAL & $-0.33^{* * *}$ & - & & & \\
\hline & TEMP & $0.43^{* * *}$ & $-0.33 * * *$ & - & & \\
\hline & CHLA & $0.14^{*}$ & 0.01 & -0.14 & - & \\
\hline
\end{tabular}




\subsection{Large-scale distribution and dynamics}

Bivalve larvae were present in the plankton of Ahe lagoon at each of the sampling periods. The average abundance ranged from $15.8 \pm 0.6 \times 10^{3} \mathrm{~m}^{-3}$ in November 2007 to $21.3 \pm 1.1 \mathrm{x}$ $10^{3} \mathrm{~m}^{-3}$ in April-May 2007 (Table 3). This constant presence is in agreement with the continuous reproductive patterns described for tropical bivalves (Pouvreau et al., 2000). Average concentrations were higher than in other atolls. In addition, bivalve larvae contribute to a large part of the zooplankton abundance in the Ahe lagoon with a contribution of $53.3 \pm$ $13.2 \%$ to the abundance (Pagano et al., this issue). In their study of Tikehau lagoon (French Polynesia), Blanchot et al. (1989) reported a mean bivalve larvae concentration of $0.9 \times 10^{3}$ $\mathrm{m}^{-3}$, ranging from $0.2 \times 10^{3}$ to $1.9 \times 10^{3} \mathrm{~m}^{-3}$, and corresponding to $6 \%$ of the plankton abundance. An average concentration of $2.1 \times 10^{3} \mathrm{~m}^{-3}$, ranging from $0.3 \times 10^{3}$ to $35.4 \times 10^{3} \mathrm{~m}^{-}$ ${ }^{3}$ was measured in the Takapoto lagoon (French Polynesia) (Garen, unpublished data).

Table 3. Water temperature, bivalve larvae concentration: mean \pm standard error $(n)$; and spat density of $P$. margaritifera, $P$. maculata and other bivalve species on collectors: mean of 6 depths \pm standard error ( $n$, relative proportion) during four survey periods (letters indicate significant differences between surveys: $\mathrm{p}<0.05$ )

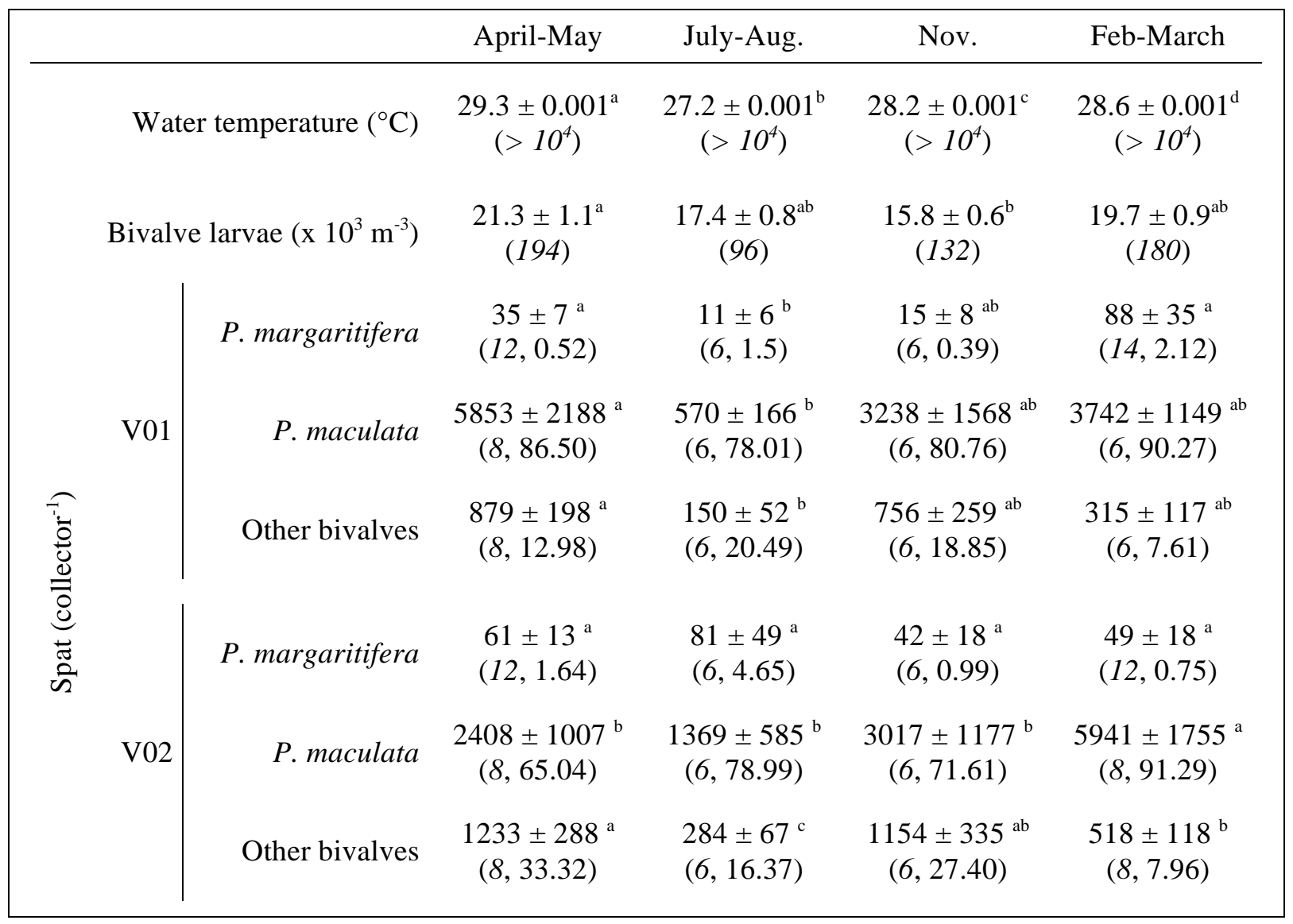


The larval concentration in Ahe lagoon appeared also very high compared with other ecosystems. A coastal lagoon of southern Portugal had an average bivalve larvae concentration around $4.7 \times 10^{3} \mathrm{~m}^{-3}$ (Chicharo and Chicharo 2000), and the inner-shelf off North Carolina yielded $9.8 \times 10^{3} \mathrm{~m}^{-3}$ (Garland et al., 2002).

The abundant population of adults in Ahe lagoon certainly explain the permanent larval abundance, which is also modulated, by larval mortality due to predation, export, and starvation. In Ahe, only the reared $P$. margaritifera stock numbers are well known (circa $15 \mathrm{x}$ $10^{6}$ individuals), not including oysters on collectors that are breeders from the age of approximately 6 months to 1 year. Although no data are available on the wild bivalve populations in Ahe lagoon, 6 bivalve species are likely present given their abundance in other Polynesian atoll lagoons: Arca ventricosa (Lamarck, 1819), Pinctada maculata, Crassostrea cucullata (Born, 1778), Spondylus varians (Sowerby, 1829), Chama iostoma (Conrad, 1837) and Tridacna maxima (Röding, 1798). An evaluation of the wild population broodstocks should be made in Ahe lagoon to evaluate the relative contribution of these species to the entire bivalve community. Our spat settlement measurement suggest that $P$. maculata would be dominant since it accounts for almost $80 \%$ of the total density (see below). Nonetheless, species selectivity of collectors is unknown and it would be hazardous to draw any direct conclusion about wild stock from this result.

During our surveys, the variability of larval abundance appeared lower on the local scale than on the large scale. Larval abundance was constant or exhibited gradient shape along the two transects (Fig. 5). This observation meant that interpretation mistakes due to small-scale patchy patterns were minimized. 

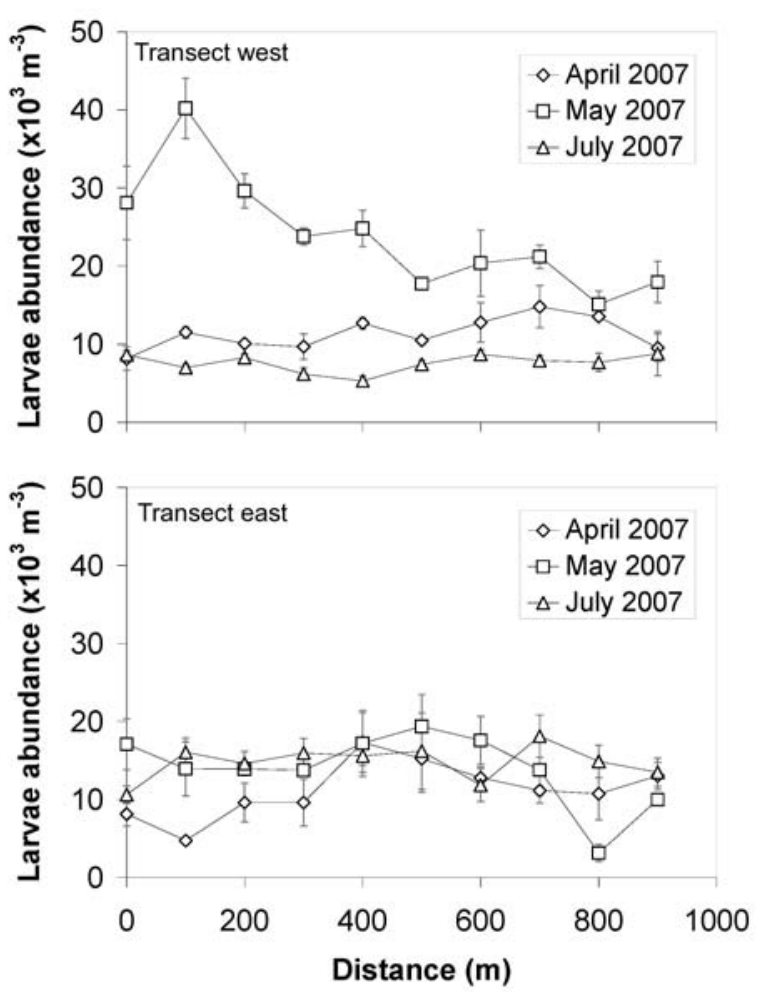

Fig. 5 Bivalve larvae abundance variation (mean \pm standard error) along the west (up) and east (down) transects, during three sampling surveys

Bivalve larvae abundances were heterogeneously distributed at the lagoon scale (Fig. 6), with a general pattern showing (i) a low concentration area in front of the pass, (ii) a high concentration area along the east reef rim and (iii) a more variable concentration area in the southwest sector. The extent of the southern high concentration sector was the most variable feature, with a minimal area during the August survey, which was the windiest period, and a shift of the 'poorest' area towards the west coast of the lagoon. A significant east-west gradient was revealed for the median size of bivalve larvae cohorts, showing higher values in the eastern sector at every survey (Fig. 6). A similar large-scale pattern was described by Carleton \& Doherty (1998) in the Taiaro atoll lagoon, with different zooplankton assemblages in windward and leeward parts of the lagoon, which they interpreted as a result of both hydrodynamic circulation and species-specific behaviour. 


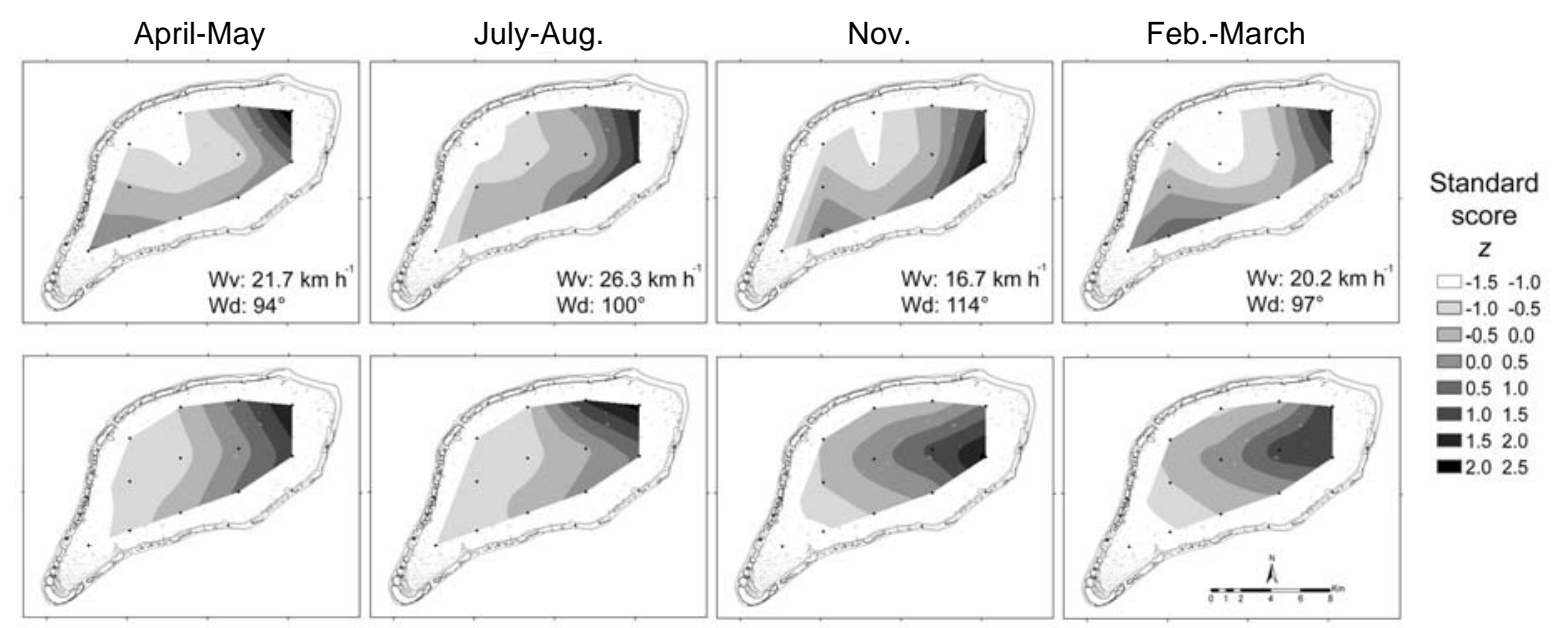

Fig. 6 Spatial variation of bivalve larvae abundance (up) and bivalve larvae median size (down), in the four surveys: (a) April-May 2007, (b) August 2007, (c) November 2007 and (c) February-March 2008. All data were standardized (standard score $z$ ). Mean wind velocity $(\mathrm{Wv})$ and wind direction $(\mathrm{Wd})$ are indicated on the maps

Ahe should be regarded as a deep lagoon, with a $40 \mathrm{~m}$ average depth and maximum depth over $70 \mathrm{~m}$. In such deep lagoons, circulation patterns are mostly wind-driven, with surface circulation going downwind and a 'compensatory' upwind current of deep water (Atkinson et al., 1981). Since the majority of larvae were actually distributed in deep layers, the vertical distribution of bivalve larvae could explain some of the observed large-scale patterns, the larvae being subjected to the 'compensatory' upwind current leading to high larval concentration along the eastern reef rim. This observation is confirmed by the study of Pagano et al. (this issue) in the Ahe lagoon, describing heterogeneity in zooplankton assemblage, with species showing a migratory behaviour concentrated in the western part of the atoll and a high concentration of bivalve larvae in the eastern part by windy conditions. The large-scale pattern could also be related to the broodstock distribution, as the majority of the cultivated broodstock is located close to the reef rim around the lagoon. The central part of the lagoon has deep waters, with few reefs suitable as adult habitat (Adjeroud et al., 2000; Pante et al., 2006). Nonetheless, the high transport potential for larvae observed in our study (see below) and confirmed by the modelling study of Thomas et al. (this issue) on the larval transport and connectivity in the Ahe lagoon, seem to minimize the effect of the broodstock location, mainly by eastern winds.

In atoll lagoons, tide residual transport and direct influence on planktonic communities exhibit a general low pattern and are mostly confined to the vicinity of the pass (Tartinville et 
al., 1997). In our study, the diluting effect of the pass was obvious and corroborated by the positive correlation between larval abundances and distance from the pass (Table 2). Stations L04, L05 and L06, located in front of the pass, and extended toward the east, were mainly submitted to this diluting effect.

The hierarchical cluster analysis (HCA) allowed 4 groups of stations with similar abundance and median size patterns and dynamics to be identified (Fig. 7): a western confined sector A, corresponding to the L01 station; a sector B, separated in two groups: one in front of the pass covering the L02, L03 and L04 station and a second in southeast, covering the stations L08, L09 and L12; an extended north sector, C, covering the stations L05, L06, L10 and L11; and a small south sector, D, corresponding to the station L07. HCA did not provide any explanation or interpretation, so the results need to be considered carefully. Indeed, as our HCA analysis did not include weighting by location proximity, the spatial and temporal continuity of two-day step data used for the HCA may induce positive spatial autocorrelations (Schabenberger and Gotway 2005). This analyse is mainly used to simplify the short-time scale patterns presentation and interpretation.

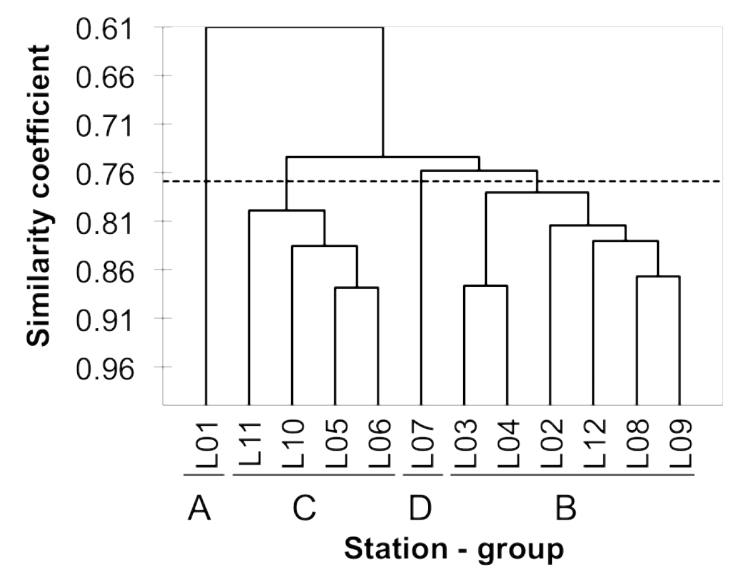

Fig. 7 Dendrogram extracted from the hierarchical cluster analysis.

Short time-scale variations were recorded in wind velocity, mostly during the three first surveys (Fig. 8a). In addition, high day-to-day variations in phytoplankton biomass were observed, concurrent to stratification/mixing events, showing higher concentration in the deeper layers (Fig. 8b). The bivalve larvae abundances and median size variations are presented on Fig. 8c and d with a two-day step frequency, according to the four groups identified by the hierarchical cluster analysis: A, B, C and D. The mean coefficients of 
variation calculated for sectors A, B, C and D were 101, 30, 32 and $54 \%$, respectively. These high levels of variation were mainly supported by the first and last surveys. Four successive increases in abundance were then observed with increasing intensity during the fourth survey in sector A (Fig. 8c). A specific event occurred during the first survey, on 8 May, with a synchronous increase in the four sectors. The abundance rise recorded in sector A also appeared delayed in the adjacent $\mathrm{D}$ area, as seen during the first survey, after the 8 May, and during the last survey, after the second and third 'larval blooms', on 19 and 25 February.

The 'larval blooms' observed during the first and last surveys were correlated with high wind occurrence, leading to the homogenisation of the water column that was recorded through the $\mathrm{Chl} a$ in vivo measurement (Fig. 8b). As revealed by the day-to-day recording, abundance variations appeared to be mostly sustained by punctual increases, which were dominant in sector A. These events were related to a decrease in median size and could then be linked to spawning events. The southwest zone can, therefore, be considered as a 'source area' for larvae, sustained by multiple 'spawning events' identified by the simultaneous increase in abundance and decrease in median size. Indeed, this sector gathers an important pearl oyster stock and several reefs suitable as adult habitat. Nevertheless, bivalve larvae abundance decreased rapidly after these 'spawning events' in L01 and reached lower values than in other areas, providing evidence of export. This west-east transfer through the southern part of the lagoon is supported by the delay of abundance rises described between sectors A and D (Fig. 8c). Furthermore, westward extension of the B and C groups shows evidence of east-west transfers. 


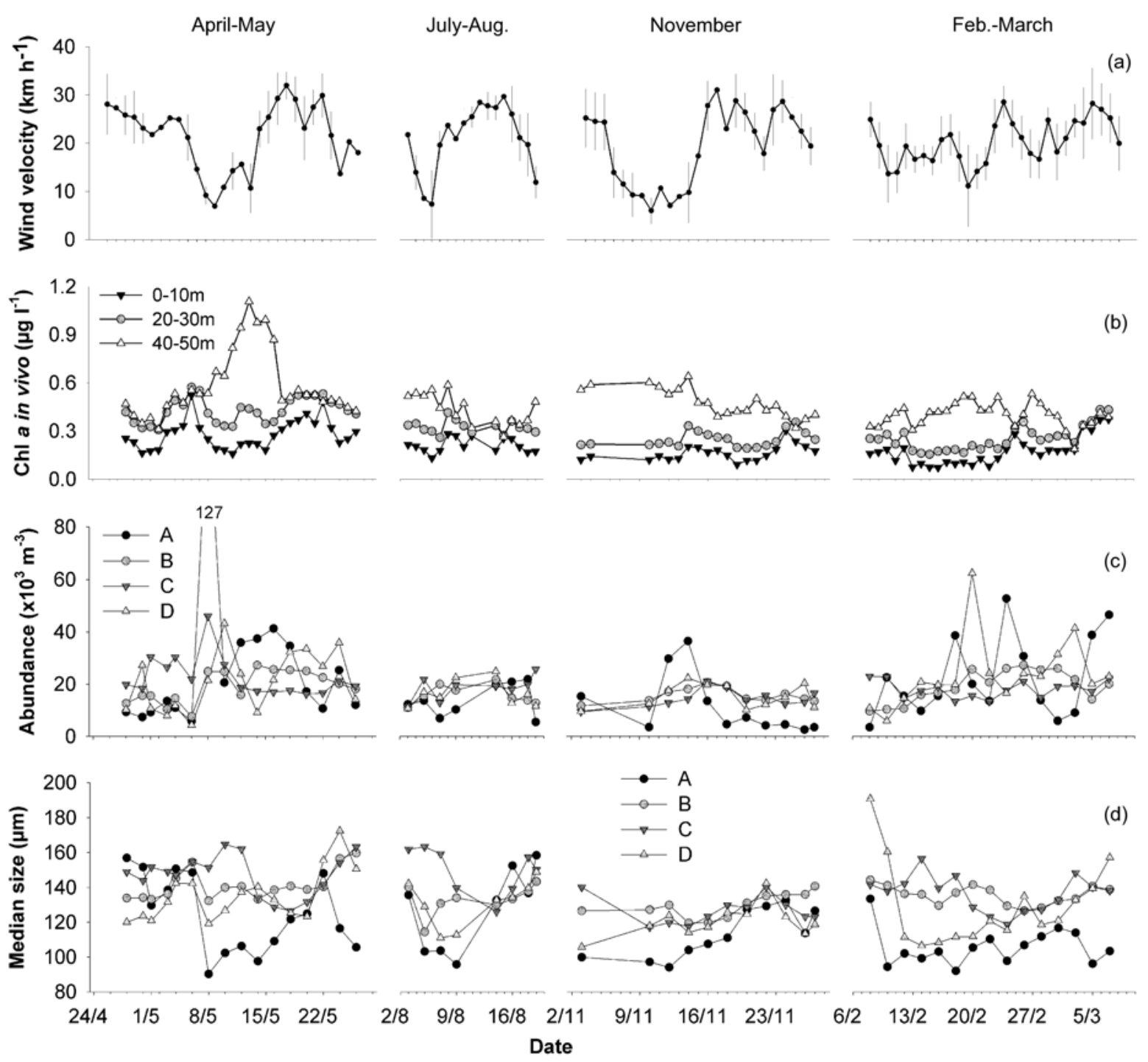

Fig. 8 Day-to-day variation in wind velocity, Chl $a$ in vivo concentration by $10 \mathrm{~m}$ depth layers, abundance of bivalve larvae and median size of bivalve larvae for the four groups of stations: A, B, C and D, during the four surveys: April-May 2007, August 2007, November 2007 and February-March 2008

A system like the counter-rotating bodies of water described by Atkinson et al. (1981) in the Enewetak atoll lagoon could explain these east-west transfers without north-south communication. Indeed, this kind of functioning has been recently described in Ahe lagoon by Dumas et al. (this issue), with the stream function displaying three main barotropic circulation structures: a flat clockwise cell along the southern rim, an anticlockwise circulation cell in the middle of the atoll, and a clockwise circulation loop along the northern rim. In addition, a high connectivity level between sectors of the Ahe lagoon has been recently confirmed by Thomas et al. (this issue), through a 3D modelling study of the larval 
transport. Indeed, they showed that the west-east transfer of larvae was supported by eastern winds, observed during the summer period, and related to the activation of a compensatory current in the deep layers. For winds coming from the southeast, mainly observed during the winter, a lower compensatory current, induced by a low fetch, implies higher retention of the larvae in their origin area.

\subsection{Bivalve larvae patterns related to environmental factors}

Correlations between environmental parameters and bivalve larvae abundances at the three spatial scales studied are presented in Table 2. Spatio-temporal variability of environmental parameters such as the temperature, salinity and phytoplanktonic communities in the Ahe lagoon were described by Thomas et al., (2010). Distances from the pass and from the eastern reef were added to the analysis in order to extract the effects of water renewal and geomorphology.

At the lagoon scale, larval abundances revealed a significant positive correlation with distance from the pass and negative correlation with distance from the eastern reef. At the local scale (i.e. transects), larval abundance showed significant positive correlation with Chl $a$ in vivo and negative correlation with salinity. Finally, at the vertical scale, larval abundance exhibited a significant positive correlation with temperature and in vivo $\mathrm{Chl} a$, and a negative correlation with salinity.

Maximal larval concentrations were recorded during the warmest periods. As already mentioned, this pattern must largely be related to oyster broodstock reproductive activity that, despite continuous reproduction, reaches a maximum during warm periods (Pouvreau et al., 2000). Reproductive pattern itself appeared closely linked to hydro-biological and/or meteorological events on a short time-scale, according to the synchronous 'spawning events' correlated with high wind occurrences recorded during the first and last surveys (Erreur ! Source du renvoi introuvable.). Bivalve molluscs are known to have stress-induced reproductive triggers (Fujikura et al., 2007). Windy conditions could, therefore, provide a physical stress factor that triggers reproduction by current modification, water mixing or the consequent modification of hydro-biological parameters (e.g. food concentration and/or availability). Indeed, Fournier et al., (This issue) showed recently that $P$. margaritifera 
developed a clear opportunistic strategy of reproduction in which gametogenesis rate and spawning are directly related to plankton concentration, itself correlated to the wind speed.

The spatial patterns described in our study showed significant heterogeneity, in agreement with the 'multiple driving force hypothesis' described by Pinel-Alloul (1995), and defined as the combination of biotic and abiotic factors controlling environmental heterogeneity. We demonstrated the primacy of abiotic factors controlling bivalve larvae heterogeneity at a large spatial scale and a greater importance of biological processes at smaller scales. At the lagoon scale, bivalve larvae abundances were then positively correlated with the distance from the pass, indicating a significant diluting effect. In addition, abundances were negatively correlated with the distance from the eastern reef, which could partly be related to hydrodynamic effects on retention or through the effect of the compensatory current in deep layers (Thomas et al., this issue). At last, the large scale heterogeneity in larval concentration may be related to the trophic resource heterogeneity described by Thomas et al. (2010) and the opportunistic strategy of reproduction of P. margaritifera described by Fournier et al. (this issue), with higher plankton concentration close to the east and west reefs, corresponding to the sectors most concentrated in larvae. On the smallest scales, larval abundances were significantly correlated with temperature, salinity and food concentration, and exhibited vertical swimming behaviour leading to vertical structuring of abundances.

\subsection{Bivalve species settlement patterns}

P. margaritifera spat appeared largely under-represented on collectors, with a relative proportion of $1.6 \%$ compared with $80.3 \%$ and $18.1 \%$ for the $P$. maculata and 'other bivalves', respectively (Table 3). P. margaritifera spat settlement on artificial collectors showed a low but significant difference $(\mathrm{p}=0.044)$ between the two stations, with higher densities at V02 (Table 3). The maximum P. margaritifera spat recruitment was recorded at 5 $m$ depth with a strong decrease below this layer (Fig. 2). No significant seasonal difference was recorded at the V02 station, and maxima were recorded in April-May and FebruaryMarch at V01.

P. maculata spat showed maximum density in the first $25 \mathrm{~m}$ (data not shown). No significant difference was recorded between stations $(\mathrm{p}>0.05)$, both showed lower abundances in August and higher during warm periods in April and February. 
'Other bivalves' showed significantly lower density at $45 \mathrm{~m}$ (data not shown) with higher abundances at V02. The same seasonal trend was recorded at both stations, showing maxima during the first and third surveys.

Several studies indicate spatial and temporal variability of benthic invertebrate larvae settlement over a wide range of scales (Porri et al., 2008). Beside the substrate selection, most studies explain this temporal and spatial variation by two related factors: hydrodynamics and larval supply (Friedman and Bell 1999). In our case, significant spatio-temporal variations were found for the P. margaritifera spat settlement. The two collecting stations exhibited different patterns: the eastern sector showing no seasonal variation, but higher settlement performances, and the western stations showing a more seasonal pattern, with higher performances during warm periods. These observations could be related to the distribution of bivalve larvae cohorts on a large scale, with high concentrations in the east and a more variable southwest area. The larval phase of $P$. margaritifera has a duration of 3-4 weeks in the laboratory (Southgate and Beer 1997). Larvae could, therefore, be exported from the southwest sector to an area with higher residence time until they reach the competent stage necessary for settlement (Le Pennec et al., 2003). Higher larval median sizes found in the eastern part of the lagoon and east-to-west connectivity in the western part of the lagoon measured during eastern wind periods corroborate this observation. As observed during the July-August survey, the windiest conditions coincided with lowest settlement westward and increasing settlement eastward, indicating that windy conditions provide favourable circumstances for west to east transport.

Vertical heterogeneity was found with maximum $P$. margaritifera settlement at $5 \mathrm{~m}$ depth, which is in agreement with previous studies and industry recommendations (Friedman and Bell 1999). However these observations differ from those made in Takapoto lagoon, where more than half of the wild stock was found in the 30-40 m depth layer (Zanini and Salvat 2000). Specific behaviour related to artificial substrates (i.e. collectors) might explain the characteristics of oysters in Ahe atoll, as chemical cues (e.g. biofilm coverage) and substrate type (i.e. deep colour, roughness) are key parameters determining attractiveness for settlement (Doroudi and Southgate 2002; Su et al., 2007), and may be depth-dependent. In addition, $P$. margaritifera spat appeared to be particularly under-represented, mainly in comparison with 
P. maculata spat. Inter-specific competition could, therefore, contribute to a part of the spatiotemporal variation in settlement on collectors.

\section{Conclusion}

Despite the low variability of hydro-biological parameters commonly assumed in atoll lagoons, we recorded significant heterogeneity of bivalve larvae abundances in the range of the spatio-temporal scales we examined. According to the 'measured heterogeneity' concept, defined as the product of the observer's perspective (Pinel-Alloul 1995), bivalve larvae appeared (i) concentrated at mid-depth with nocturnal ascent and daytime descent, (ii) heterogeneously dispersed at the lagoon scale, (iii) exhibited day-to-day abundance variations and (iv) transferred between sectors of the lagoon. These transfers provide evidence for intralagoonal connectivity and, therefore, for potential source and sink sectors. According to the ‘functional heterogeneity' concept (Pinel-Alloul 1995), which arises from the ecological interactions between ecological entities and their environment, we identified (i) the primacy of physical factors at a large spatial scale, with the diluting effect of renewal and large-scale hydrodynamic transfers, and (ii) the primacy of biological processes at smaller scales, showing larval swimming activity leading to vertical migrations positively correlated with food concentration. Small time-scale abundance variations also appeared to be driven by reproductive activity, itself correlated with meteorological conditions (i.e. windy periods). Finally, we demonstrated the positive relationship between bivalve larvae abundance and $P$. margaritifera settlement abundance. However, only species identification at larval stages should provide more information between small-scale larval patterns and spat settlement. To this end, whole mount in situ hybridisation technique recently developed to allow the discrimination of closely-related pearl oyster larvae species found in the French Polynesian atolls (Thomas et al., 2011), might be a relevant tool.

\section{Acknowledgments}

This study was funded by the Institut Français de Recherche pour l'Exploitation de la Mer (Ifremer) and the French Polynesian government (research delegation) with technical support of the Service de la Perliculture. Authors wish to express their gratitude to the Ifremer and Service de la Perliculture staff for their efficient help during sample collection. We also thank the Pa'umotu: the Maifano family for their effective assistance on Ahe atoll. We thank $\mathrm{H}$. McCombie for her helpful comments and English revision. 


\section{References}

Adjeroud, M., Andréfouët, S., Payri, C., Orempuller, J., 2000. Physical factors of differentiation in macrobenthic communities between atoll lagoons in the Central Tuamotu Archipelago (French Polynesia). Marine Ecology-Progress Series 196, 25-38

Andréfouët, S., Yamano, H., submitted. High resolution mapping of semi-enclosed atoll rims for the characterisation of hydrodynamic processes: the case of Ahe and Takaroa (Tuamotu Archipelago). Marine Pollution Bulletin, this issue

Atkinson, M., Smith, S.V., Stroup, E.D., 1981. Circulation in Enewetak atoll lagoon. Limnology and Oceanography 26, 1074-1083

Avois-Jacquet, C., 2002. Variabilité spatiale multiéchelle du zooplancton dans un lagon récifal côtier. phD dissertation, Université Paris 6, France Université de Montréal, Canada

Badylak, S., Phlips, E.J., 2008. Spatial and temporal distributions of zooplankton in Tampa Bay, Florida, including observations during a HAB event. Journal of Plankton Research 30, 449-465

Baker, P., 2003. Two species of oyster larvae show different depth distributions in a shallow, well-mixed estuary. Journal of Shellfish Research 22, 733-736

Blanchot, J., Charpy, L., Le Borgne, R., 1989. Size Composition of Particulate Organic Matter in the Lagoon of Tikehau Atoll Tuamotu Archipelago Pacific Ocean. Marine Biology 102, 329-340

Borcard, D., Legendre, P., Avois-Jacquet, C., Tuomisto, H., 2004. Dissecting the spatial structure of ecological data at multiple scales. Ecology 85, 1826-1832

Botsford, L.W., White, J.W., Coffroth, M.A., Paris, C.B., Planes, S., Shearer, T.L., Thorrold, S.R., Jones, G.P., 2009. Connectivity and resilience of coral reef metapopulations in marine protected areas: matching empirical efforts to predictive needs. Coral Reefs 28, $327-337$

Carleton, J.H., Doherty, P.J., 1998. Tropical zooplankton in the highly-enclosed lagoon of Taiaro Atoll (Tuamotu Archipelago, French Polynesia). Coral-Reefs 17, 29-35

Chicharo, L.M.Z., Chicharo, M.A., 2000. Short-term fluctuations in bivalve larvae compared with some environmental factors in a coastal lagoon (South Portugal). Scientia Marina $64,413-420$

Cowen, R.K., Lwiza, K.M.M., Sponaugle, S., Paris, C.B., Olson, D.B., 2000. Connectivity of marine populations: Open or closed? Science 287, 857-859 
Cowen, R.K., Paris, C.B., Srinivasan, A., 2006. Scaling of connectivity in marine populations. Science $311,522-527$

Doroudi, M.S., Southgate, P.C., 2002. The effect of chemical cues on settlement behaviour of blacklip, pearl oyster (Pinctada margaritifera) larvae. Aquaculture 209, 117-124

Doroudi, M.S., Southgate, P.C., Mayer, R.J., 1999. The combined effects of temperature and salinity on embryos and larvae of the black-lip pearl oyster, Pinctada margaritifera (L.). Aquaculture Research 30, 271-277

Dumas, F., Le Gendre, R., Thomas, Y., Andréfouët, S., submitted. Tidal flushing and wind driven circulation of Ahe lagoon (Tuamotu Archipelago, French Polynesia) from in situ observations and numerical modelling. Marine Pollution Bulletin, this issue

Eckman, J.E., 1996. Closing the larval loop: Linking larval ecology to the population dynamics of marine benthic invertebrates. Journal of Experimental Marine Biology and Ecology 200, 207-237

Fortier, L., Leggett, W.C., 1982. Fickian transport and the dispersal of fish larvae in estuaries. Canadian Journal of Fisheries and Aquatic Sciences 39, 1150-1163

Fournier, J., Levesque, E., Pouvreau, S., Le Pennec, M., Le Moullac, G., submitted. Influence of plankton concentration on gametogenesis and spawning of the blacklip pearl oyster P. margaritifera in Ahe atoll lagoon (Tuamotu Archipelago, French Polynesia). Marine Pollution Bulletin. This issue

Friedman, K.J., Bell, J.D., 1999. Variation in abundance of blacklip pearl oyster (Pinctada margaritifera Linne.) spat from inshore and offshore reefs in Solomon Islands. Aquaculture 178, 273-291

Fujikura, K., Amaki, K., Barry, J.P., Fujiwara, Y., Furushima, Y., Iwase, R., Yamamoto, H., Maruyama, T., 2007. Long-term in situ monitoring of spawning behavior and fecundity in Calyptogena spp. Marine Ecology-Progress Series 333, 185-193

Garland, E.D., Zimmer, C.A., Lentz, S.J., 2002. Larval distributions in inner-shelf waters: The roles of wind-driven cross-shelf currents and diel vertical migrations. Limnology and Oceanography 47, 803-817

Haury, L., McGowan, J., Wiebe, P., 1978. Patterns and processes in the time-space scales of plankton distribution. In: Steele JH (ed) Spatial pattern in plankton communities Plenum Press, New York, p 277-327

Hofmann, E.E., Powell, E.N., Bochenek, E.A., Klinck, J.A., 2004. A modelling study of the influence of environment and food supply on survival of Crassostrea gigas larvae. Ices Journal of Marine Science 61, 596-616 
ISPF, 2008. Regards sur l'économie de l'année 2008. Institut de la Statistique de la Polynésie française, Regards n ${ }^{\circ} 19,94 \mathrm{pp}$

Knights, A.M., Crowe, T.P., Burnell, G., 2006. Mechanisms of larval transport: vertical distribution of bivalve larvae varies with tidal conditions. Marine Ecology-Progress Series 326, 167-174

Le Pennec, M., Paugam, A., Le Pennec, G., 2003. The pelagic life of the pectinid Pecten maximus - a review. Ices Journal of Marine Science 60, 211-223

Levin, L.A., 2006. Recent progress in understanding larval dispersal: new directions and digressions. Integrative and Comparative Biology 46, 282-297

Masson, S., Pinel-Alloul, B., Dutilleul, P., 2004. Spatial heterogeneity of zooplankton biomass and size structure in southern Quebec lakes: variation among lakes and within lake among epi-, meta- and hypolimnion strata. Journal of Plankton Research 26, $1441-1458$

Munday, P.L., Leis, J.M., Lough, J.M., Paris, C.B., Kingsford, M.J., Berumen, M.L., Lambrechts, J., 2009. Climate change and coral reef connectivity. Coral Reefs 28, 379-395

Olson, R.R., Olson, M.H., 1989. Food limitation of planktonic marine invertebrate larvae does it control recruitment success? Annual Review of Ecology and Systematics 20, $225-247$

Pace, D.A., Marsh, A.G., Leong, P.K., Green, A.J., Hedgecock, D., Manahan, D.T., 2006. Physiological bases of genetically determined variation in growth of marine invertebrate larvae: A study of growth heterosis in the bivalve Crassostrea gigas. Journal of Experimental Marine Biology and Ecology 335, 188-209

Pagano, M., Sagarra, P. B., Champalbert, G., Bouvy, M., Dupuy, C., Thomas, Y., Charpy, L., submitted. Structure and dynamics of metazooplankton communities in an atoll lagoon (Ahe, Tuamotu Archipelago, French Polynesia). Marine Pollution Bulletin, this issue

Pagès, J., Andrefouet, S., 2001. A reconnaissance approach for hydrology of atoll lagoons. Coral Reefs 20, 409-414

Pante, E., Adjeroud, M., Dustan, P., Penin, L., Schrimm, M., 2006. Spatial patterns of benthic invertebrate assemblages within atoll lagoons: importance of habitat heterogeneity and considerations for marine protected area design in French Polynesia. Aquatic Living Resources 19, 207-217 
Paugam, A., D'Ollone, C., Cochard, J.C., Garen, P., Le Pennec, M., 2006. The limits of morphometric features for the identification of black-lip pearl oyster (Pinctada margaritifera) larvae. Journal of Shellfish Research 25, 959-967

Pinel-Alloul, B., 1995. Spatial heterogeneity as a multiscale characteristic of zooplankton community. Hydrobiologia 300, 17-42

Porri, F., McQuaid, C.D., Lawrie, S.M., Antrobus, S.J., 2008. Fine-scale spatial and temporal variation in settlement of the intertidal mussel Perna perna indicates differential hydrodynamic delivery of larvae to the shore. Journal of Experimental Marine Biology and Ecology 367, 213-218

Pouvreau, S., Gangnery, A., Tiapari, J., Lagarde, F., Garnier, M., Bodoy, A., 2000. Gametogenic cycle and reproductive effort of the tropical blacklip pearl oyster, Pinctada margaritifera (Bivalvia : Pteriidae), cultivated in Takapoto atoll (French Polynesia). Aquatic Living Resources 13, 37-48

Powell, E.N., Bochenek, E.A., Klinck, J.M., Hofmann, E.E., 2002. Influence of food quality and quantity on the growth and development of Crassostrea gigas larvae: a modeling approach. Aquaculture 210, 89-117

Raby, D., Lagadeuc, Y., Dodson, J.J., Mingelbier, M., 1994. Relationship between feeding and vertical distribution of bivalve larvae in stratified and mixed waters. Marine Ecology-Progress Series 103, 275-284

Roberts, C.M., 1997. Connectivity and management of Caribbean coral reefs. Science 278, $1454-1457$

Schabenberger, O., Gotway, C.A., 2005. Statistical methods for spatial data analysis. Texts in statistical science ed Chapman \& hall/CRC, 488pp

Southgate, P.C., Beer, A.C., 1997. Hatchery and early nursery culture of the blacklip pearl oyster (Pinctada margaritifera L.). Journal of Shellfish Research 16, 561-567

Su, Z.X., Huang, L.M., Yan, Y., Li, H.X., 2007. The effect of different substrates on pearl oyster Pinetada martensii (Dunker) larvae settlement. Aquaculture 271, 377-383

Swearer, S.E., Caselle, J.E., Lea, D.W., Warner, R.R., 1999. Larval retention and recruitment in an island population of a coral-reef fish. Nature 402, 799-802

Tartinville, B., Deleersnijder, E., Rancher, J., 1997. The water residence time in the Mururoa atoll lagoon: Sensitivity analysis of three-dimensional model. Coral-Reefs 16, 193-203

Thomas, Y., Belliard, C., Garen, P., Gueguen, Y., Montagnani, C., 2011. Development of in situ hybridisation of $16 \mathrm{~S}$ rRNA to monitor black-lip pearl oyster (Pinctada margaritifera L.) larvae. Aquatic Living Resources 24, 27-34 
Thomas, Y., Garen, P., Courties, C., Charpy, L., 2010. Spatial and temporal variability of the pico- and nanophytoplankton and bacterioplankton in a deep Polynesian atoll lagoon. Aquatic Microbial Ecology 59, 89-101

Thomas, Y., Le Gendre, R., Garen, P., dumas, F., Andréfouët, S., submitted. Bivalve larvae transport and connectivity within the Ahe atoll lagoon (Tuamotu Archipelago), with application to pearl oyster aquaculture management. Marine Pollution Bulletin, this issue

Troost, K., Gelderman, E., Kamermans, P., Smaal, A.C., Wolff, W.J., 2009. Effects of an increasing filter feeder stock on larval abundance in the Oosterschelde estuary (SW Netherlands). Journal of Sea Research 61, 153-164

Zanini, J.M., Salvat, B., 2000. Assessment of deep water stocks of pearl oysters at Takapoto Atoll (Tuamotu Archipelago, French Polynesia). Coral Reefs 19, 83-87 